\title{
SIFAT-SIFAT SEASONING ALAMI JAMUR MERANG (Volvariella volvaceae) TERFERMENTASI MENGGUNAKAN TAPIOKA TEROKSIDASI SEBAGAI BAHAN PENGISI
}

The Natural Seasoning Properties of Fermented Paddy Straw Mushrooms (Volvariella volvaceae) by Oxidized Tapioca as Filler

\author{
Yhulia Praptiningsih $^{1)} *$, Niken Widya Palupi ${ }^{1)}$, Triana Lindriati ${ }^{1)}$, Inna Manikam Wahyudi $^{1)}$ \\ ${ }^{1)}$ Jurusan Teknologi Hasil Pertanian, Fakultas Teknologi Pertanian Universitas Jember \\ Jalan Kalimantan 37, Kampus Tegal Boto, Jember 68121 \\ *E-mail: yhuliaprapti@gmail.com
}

\begin{abstract}
The paddy straw mushroom can be make natural seasoning, because it has content of protein $17.01 \%(\mathrm{db})$ which completely of amino acids composition, high content of glutamic acid and aspartic acid. Producing of natural seasoning from paddy straw mushrooms which has along life storage, practice and flexible, it is need of salted fermentation to hydrolyze of mushrooms protein. The aim of this research was to reach of the appropriate proportion of salted fermented paddy straw mushrooms and oxidized tapioca as a filler to produce the good properties and high preference of fermented paddy straw mushrooms seasoning. The yield of this research showed that the good treatment was the proportion of salted fermented paddy straw mushrooms and oxidized tapioca 75:25. The seasoning had the moisture content $14.1 \%$, total protein $17.98 \%(\mathrm{db})$, soluble protein $4.51 \%(\mathrm{db})$, brightness 61.55, solubility 8.22 seconds, the preference score of colour 3.28 (rather like until like), aroma 2.92 (little like until rather like), taste 3.06 (little like until rather like), and overall 3(rather like).
\end{abstract}

Keywords: natural seasoning, fermented paddy straw mushrooms, oxidized tapioca, filler

\section{PENDAHULUAN}

Jamur merang (Volvariella volvaceae) mudah budidayanya sehingga mempunyai potensi yang besar untuk dikembangkan. Pemanfaatan jamur merang masih terbatas yaitu untuk pelengkap sayur dan dibuat makanan ringan (keripik dan krispi). Jamur merang mengandung protein cukup tinggi 17,01 $\%$ (db) dengan kadar air 81\%, komposisi asam amino lengkap dengan proporsi asam glutamat dan asam aspartat tertinggi dibandingkan jenis asam amino yang lain (Drogba et al., 2012). Proporsi asam glutamat (10-35 \%) dan asam aspartat (10-11,6 \%) dari total protein, tergantung umur pemanenan jamur (Mau et al., 1997).

Kandungan protein yang cukup tinggi dengan proporsi asam glutamat tinggi pada jamur merang, memungkinkan dibuat seasoning alami atau penyedap rasa.

Penyedap rasa komersial sebagian besar terbuat dari bahan berupa asam amino L atau garamnya dan 5-nukleotida (5-IMP dan 5-GMP) (Zhang et al., 2013). Garam asam amino L yang banyak digunakan sebagai bahan penyedap rasa adalah monosodium glutamate (MSG). MSG merupakan garam natrium dari asam glutamat yang dapat terurai menjadi natrium dan glutamat, yang merupakan sumber natrium tinggi. MSG mengandung glutamat $78,2 \%$, natrium $12,2 \%$ dan air 9,6\%. Keamanan penggunaan MSG diragukan, karena apabila penggunaannya berlebihan dapat bersifat karsinogenik dan menyebabkan penyakit Chinese Restaurant Syndrome. MSG mampu memenuhi kebutuhan garam tubuh 20$30 \%$, sehingga dalam konsentrasi tinggi 
dapat menyebabkan kenaikan kadar garam dalam darah (Sand, 2005).

Pada tahun 2007, sebanyak $77,8 \%$ masyarakat Indonesia mengkonsumsi MSG. Konsumsi MSG masyarakat Indonesia cukup tinggi yaitu 1,53 g/orang/hari. Konsumsi MSG sebaiknya maksimal 0,6 g/orang/hari. Menurut WHO maksimal konsumsi MSG adalah $120 \mathrm{mg} / \mathrm{kg}$ berat badan (Data Riset Kesehatan Dasar, 2007).

Peningkatan kesadaran masyarakat akan hidup sehat, antara lain dengan menjaga keamanan pangan dan kesehatan, maka perlu dicari bahan pangan lain sebagai sumber asam glutamat alami yang dapat menggantikan penyedap rasa komersial. Salah satu jenis pangan tersebut adalah jamur merang.

Penggunaan jamur merang sebagai sumber asam amino glutamat alami memerlukan suatu teknologi pengolahan tertentu misalnya fermentasi. Pengolahan tersebut dapat meningkatkan potensi dan efektifitas jamur merang sebagai sumber asam amino glutamat, praktis dan dapat memiliki daya simpan tinggi. Salah satu cara untuk meningkatkan daya simpan adalah dengan fermentasi alami menggunakan garam. Kadar garam bubuk jamur merang terfermentasi cukup tinggi (60\%) (Maslikhah, 2015). Garam bersifat mengikat air sehingga menurunkan aktivitas air bahan dan mikroba tidak dapat tumbuh.

Fermentasi menggunakan garam merupakan fermentasi alami dengan menseleksi mikroba yang tumbuh. Mikroba tersebut menghasilkan enzim protease yang dapat menghidrolisis protein menjadi peptida rantai pendek dan asam-asam amino (Fellow, 1988; Kim et al., 2003). Hal ini mengacu fermentasi pada pembuatan kecap dan sejenisnya. Fermentasi jamur merang menggunakan larutan garam $10 \%$ selama 3 hari, menghasilkan bubuk jamur merang dengan rendemen tinggi $(17,26 \%)$ dan kadar protein terlarut tinggi $(3,43 \% \mathrm{db})$ (Maslikhah, 2015).

Penyedap rasa dapat berupa bubuk, blok maupun granul. Pembuatan penyedap rasa dalam bentuk granul dapat dilakukan menggunakan ekstruder. Pembuatan penyedap rasa menggunakan ekstruder perlu penambahan bahan pengkapsul, yang berfungsi sebgai bahan pengisi sehingga mempermudah dan mempercepat proses ekstrusi maupun pengeringan, serta mengurangi kehilangan komponen-komponen volatil dalam bahan. Komponen pembangkit citarasa mudah mengalami penguapan selama proses.

Bahan pengkapsul yang dapat digunakan antara lain tapioka teroksidasi. Tapioka teroksidasi merupakan modifikasi tapioka dengan mengoksidasi gugus hidroksil bebas menjadi gugus karboksil yang bermuatan negatif menggunakan hidrogen peroksida sebagai agensia oksidasi (Palupi, 2010; Harmon et al., 1971). Oksidasi tapioka menggunakan hidrogen peroksida menyebabkan terjadinya reaksi dengan gugus hidroksil bebas dalam rantai molekul pati membentuk gugus karbonil dan karboksil. Reaksi tersebut menyebabkan terjadinya hidrolisis ikatan glikosidik pada pati. Hal ini menyebabkan depolimerisasi pati, penurunan viskositas dan meningkatkan transparansi gel pati (Harper and Herpworth, 1981; Parovuory et al., 1995). Tapioka teroksidasi dapat membentuk matriks dengan ion kalsium sehingga dapat digunakan sebagai pengkapsul. Tapioka teroksidasi dapat digunakan sebagai pengganti bahan pengkapsul lain seperti gum arab maupun alginat. Enkapsulasi antioksidan ampas kopi dengan hasil baik menggunakan tapioka teroksidasi 25\% sebagai pensubstitusi alginat (Palupi and Praptiningsih, 2016).

Gel tapioka teroksidasi mempunyai sifat lebih jernih, retrogradasi dan kekentalan lebih rendah dibandingkan tapioka alami. Tapioka alami mempunyai 
kejernihan 0,424 abs, gugus karboksil $0,116 \%$, viskositas $57,75 \mathrm{mPas}$ (pada $47^{\circ} \mathrm{C}$ ) dan $18,75 \mathrm{mPas}$ (pada $65^{\circ} \mathrm{C}$ ), $W H C$ (water holding capacity) $0,89 \mathrm{~g}$ air/g pati; sedangkan tapioka teroksidasi mempunyai kejernihan 0,03 abs, gugus karboksil $0,433 \%$,viskositas $18,0 \mathrm{mPas}$ (pada $47^{\circ} \mathrm{C}$ ) dan 12,5 mPas (pada $65^{\circ} \mathrm{C}$ ) dan $W H C$ $0,99 \mathrm{~g}$ air/g pati. Tapioka teroksidasi mempunyai residu $\mathrm{H}_{2} \mathrm{O}_{2}$ sebesar 0,672 $\%$, jauh di bawah konsentrasi maksimum yang diijinkan oleh FDA dan GRASS yaitu $15 \%$. Jadi tapioka teroksidasi aman digunakan untuk produk pangan (Praptiningsih and Palupi, 2014). Penggunaan bahan pengisi ini perlu dibatasi, apabila penggunaan berlebihan maka dapat mengurangi intensitas penyedap rasa, dan apabila penggunaan terlalu sedikit maka fungsi sebagai bahan pengisi maupun pengkapsul kurang maksimal.

Pembuatan seasoning alami dengan sifat-sifat baik dan disukai dari jamur merang terfermentasi secara ekstrusi dingin perlu pengaturan proporsi antara jamur merang terfermentasi dengan tapioka teroksidasi. Oleh karena itu perlu dilakukan penelitian.

Tujuan penelitian adalah untuk memperoleh proporsi yang tepat antara bubuk jamur merang terfermentasi dengan tapioka teroksidasi, sehingga dihasilkan bubuk jamur merang dengan karakteristik baik dan disukai.

\section{METODE PENELITIAN}

\section{Alat dan Bahan}

Peralatan yang digunakan timbangan analitis (Ohaus), $\mathrm{pH}$ meter (Jenwey 3320), hot plate, magnetic stirrer, colour reader,pengering kabinet, oven, spektrofotometer, oven,kjeldahl apparatus, thermometer, alat-alat gelas, blender, sentrifus, vortex, ayakan 80 mesh, ekstruder (health noodle).

Bahan penelitian yang digunakan adalah jamur merang, tapioka merk 99 produksi Malang, garam, gula, lada dan bawang putih. Bahan kimia yang digunakan $\mathrm{NaOH}, \mathrm{H}_{2} \mathrm{O}_{2}, \mathrm{Na}_{2} \mathrm{CO}_{3}, \mathrm{CuSO}_{4}$, $\mathrm{H}_{2} \mathrm{SO}_{4}$, tartrat, reagen folin, aquades.

\section{TahapanPenelitian}

Penelitian ini merupakan pure experiment yang terdiri empat kegiatan yaitu: (1) pembuatan bubuk jamur merang terfermentasi, (2) pembuatan tapioka teroksidasi, (3) pembuatan seasoning alami jamur merang terfermentasi dengan variasi proporsi bubuk jamur merang dan tapioka teroksidasi, (4) analisis sifat fisik, khemis, sensoris dan penentuan perlakuan terbaik. Pembuatan bubuk jamur merang
terfermentasi

Jamur merang sebanyak $300 \mathrm{~g}$ dicuci, dipotong menjadi empat bagian, diblanching dengan direbus menggunakan air mendidih (hot water blanching) selama 3 menit. Blanching bertujuan untuk inaktivasi enzim polifenol oksidase, mempermudah ekstraksi protein dan untuk mendenaturasi protein. Jamur dihancurkan menggunakan air dengan perbandingan (jamur:air $=1: 1$ ), dicampur dengan garam $10 \%$ dari berat suspensi dan difermentasi pada suhu ruang selama 3 hari dengan diaduk secara periodik. Hasil fermentasi dipanaskan pada suhu $100{ }^{\circ} \mathrm{C}$ selama 10 menit, untuk mematikan mikroba dan enzim, dikeringkan pada suhu $60{ }^{\circ} \mathrm{C}$ selama 24 jam, dihaluskan menggunakan chopper dan dihasilkan bubuk jamur merang terfermentasi (Maslikhah, 2015).

\section{Pembuatan tapioka teroksidasi}

Tapioka sebanyak $42 \mathrm{~g}$ dilarutkan dalam $100 \mathrm{ml}$ aquades, diaduk menggunakan magnetic stirrer dan ditambahkan $\mathrm{NaOH} 2 \mathrm{~N}$ hingga diperoleh pH 7 dan diaduk menggunakan magnetic stirrer selama 15 menit, ditambahkan $1,5 \% \quad(\mathrm{v} / \mathrm{v}) \quad \mathrm{H}_{2} \mathrm{O}_{2} \quad$ dan diaduk menggunakan magnetic stirrer selama 60 
menit. Suspensi yang dihasilkan disentrifus selama 15 menit untuk memisahkan padatan. Padatan yang diperoleh dikeringkan pada suhu $50^{\circ} \mathrm{C}$ selama 18 jam, digiling dan diayak dengan ukuran 80 mesh, dihasilkan tapioka teroksidasi (Praptiningsih and Palupi, 2014).

Pembuatan seasoning alami jamur merang terfermentasi

Campuran bubuk jamur merang terfermentasi dan tapioka teroksidasi dengan proporsi sesuai perlakuan (bubuk jamur merang terfermentasi:tapioka teroksidasi $=80: 20 ; 75: 25 ; 70: 30 ; 65: 35$; 60:40), dicampur dengan air (perbandingan air dan bahan $=1: 2$ ), kemudian diekstrusi selama 20 menit dengan penambahan bumbu-bumbu (gula $2 \%$, lada $2 \%$, bawang putih $2 \%$ dari campuran bubuk jamur merang terfermentasi dan tapioka teroksidadsi). Hasil ekstrusi dikeringkan dalam pengering kabinet suhu $50^{\circ} \mathrm{C}$ selama 4 jam, dan dihasilkan seasoning bubuk jamur merang terfermentasi.

\section{Rancangan Percobaan}

Penelitian ini menggunakan rancangan acak lengkap. Faktor yang digunakan adalah faktor tunggal yaitu proporsi berat bubuk jamur merang terfermentasi dengan tapioka teroksidasi yang terdiri dari lima level $(80: 20 ; 75: 25$; $70: 30 ; 65: 35 ; 60: 40)$.

\section{Parameter Analisis}

Parameter yang diamati meliputi warna/kecerahan (menggunakan colour reader), kadar air (metode thermogravimetri; Sudarmaji et al., 1997), kadar protein (metode mikro Kjeldahl, Sudarmaji et al., 1997), kadar protein terlarut (metode Lowry, Sudarmaji et al., 1997), daya larut (pengukuran waktu larut), produk maillard (spektroskopi), sifat organoleptik meliputi kesukaan warna, aroma, rasa, dan kesukaan keseluruhan (uji kesukaan, Mabesa, 1986) dengan skala hedonik: 1. tidak suka, 2. sedikit suka, 3. agak suka, 4. suka, 5. sangat suka, kenampakan seasoning (pemotretan). Penentuan perlakuan terbaik (uji efektivitas, de Garmo et al., 1984).

\section{HASIL DAN PEMBAHASAN}

\section{Kecerahan}

Berdasarkan sidik ragam menunjukkan bahwa proporsi bubuk jamur merang terfermentasi dan tapioka teroksidasi berpengaruh terhadap kecerahan seasoning. Peningkatan proporsi tapioka teroksidasi menyebabkan peningkatan kecerahan seasoning yang dihasilkan (Gambar 1).

Hal ini karena bubuk jamur merang terfermentasi berwarna kecoklatan, sedangkan tapioka teroksidasi berwarna putih cerah.

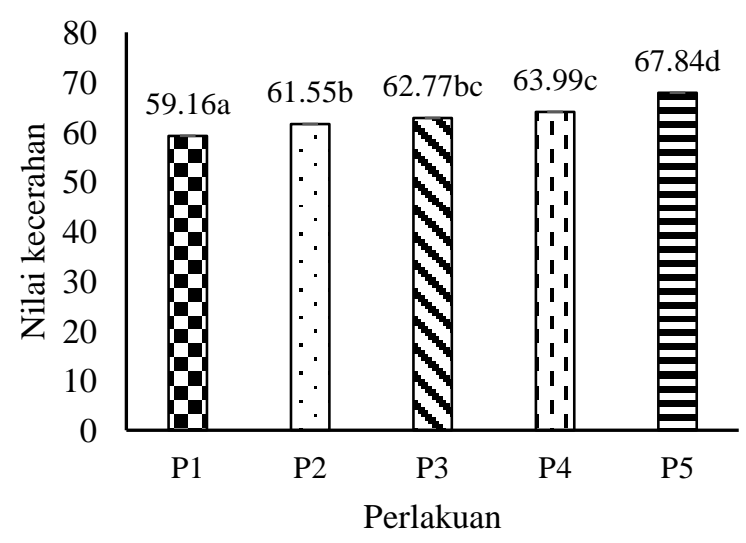

Gambar 1. Kecerahan warna seasoning alami pada berbagai proporsi jamur merang terfermentasi dan tapioka teroksidasi $(\mathrm{P} 1=80: 20 ; \mathrm{P} 2=75: 25 ; \mathrm{P} 3=70: 30$; $\mathrm{P} 4=65: 35 ; \mathrm{P} 5=65: 35$ )

Peningkatan kecerahan warna karena peningkatan proporsi tapioka teroksidasi disebabkan karena gel tapioka teroksidasi mempunyai warna cerah. Semakin banyak proporsi tapioka teroksidasi, maka terbentuknya gel banyak dan warna semakin cerah (Praptiningsih and Palupi, 2014). 
Semakin rendahnya nilai kecerahan seasoning dengan semakin tinggi proporsi tapioka teroksidasi, juga disebabkan karena semakin rendahnya intensitas reaksi maillard yang ditunjukkan dengan semakin rendahnya produk maillard (Gambar 5). Hal ini karena semakin rendah kadar protein terlarut (Gambar 4). Reaksi maillard terjadi antara gugus amina primer dari asam amino dan protein dengan gugus karbonil dari gula pereduksi (Meyer, 1978).

\section{Kadar Air}

Berdasarkan sidik ragam, proporsi bubuk jamur merang terfermentasi dengan tapioka teroksidasi berpengaruh terhadap kadar air seasoning. Peningkatan proporsi tapioka teroksidasi menyebabkan penurunan kadar air (Gambar 2). Peningkatan proporsi tapioka teroksidasi berarti penurunan proporsi bubuk jamur merang terfermentasi.

Bubuk jamur merang mengandung protein lebih tinggi dibandingkan tapioka teroksidasi, dan bubuk jamur merang juga mengandung serat. Kadar protein jamur merang $17,01 \%$ (db) (Drogba et al., 2012). Kadar protein tapioka 0,57 \% (db) (Depkes RI., 1988). WHC antara lain ditentukan oleh kadar protein, serat dan pati. WHC suatu pangan adalah kemampuan untuk memerangkap air dan menahannya di dalam struktur pangan, baik air yang ada di dalam pangan maupun air yang ditambahkan selama proses. WHC merupakan sifat fisik. Apabila $W H C$ semakin tinggi maka kadar air bahan juga semakin tinggi (Zayas, 1997). WHC bubuk jamur merang teroksidasi diduga lebih tinggi daripada $W H C$ tapioka teroksidasi, karena kadar proteinnya lebih tinggi dan adanya serat.

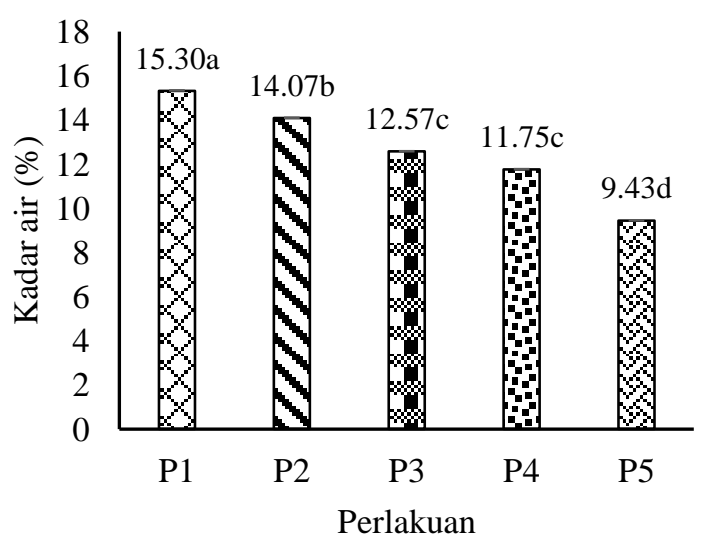

Gambar 2. Kadar air seasoning alami pada berbagai proporsi jamur merang terfermentasi dan tapioka teroksidasi $(\mathrm{P} 1=80: 20 ; \mathrm{P} 2=75: 25 ; \mathrm{P} 3=70: 30$; $\mathrm{P} 4=65: 35 ; \mathrm{P} 5=65: 35$ )

Protein pada umumnya memiliki WHC tinggi. Berdasarkan Gambar 2 ditunjukkan bahwa penurunan proporsi bubuk jamur merang terfermentasi menyebabkan penurunan kadar air seasoning yang dihasilkan. Hal ini karena kadar protein semakin turun dengan penurunan proporsi bubuk jamur merang terfermentasi, sehingga $W H C$ semakin turun dan kadar air semakin rendah. Sebaliknya, semakin tinggi konsentrasi protein maka $W H C$ semakin tinggi (Zayas, 1997).

\section{Kadar Protein}

Berdasarkan sidik ragam, proporsi bubuk jamur merang terfermentasi dengan tapioka teroksidasi berpengaruh terhadap kadar protein seasoning. Peningkatan proporsi tapioka teroksidasi menyebabkan penurunan kadar protein seasoning (Gambar 3).

Hal ini karena peningkatan proporsi tapioka teroksidasi, berarti penurunan proporsi bubuk jamur merang terfermentasi. Kandungan protein jamur merang $(17,01 \%$ db) lebih tinggi daripada tapioka $(0,5 \%$, atau $0,57 \% \mathrm{db})$ (Drogba et. al., 2012; Depkes RI, 1988). 


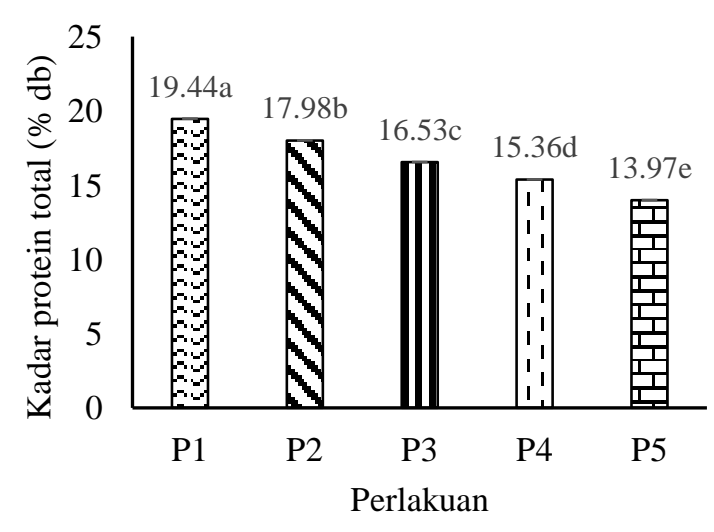

Gambar 3. Kadar protein seasoning alami pada berbagai proporsi jamur merang terfermentasi dan tapioka teroksidasi $(\mathrm{P} 1=80: 20 ; \quad \mathrm{P} 2=75: 25 ; \quad \mathrm{P} 3=70: 30$; $\mathrm{P} 4=65: 35 ; \mathrm{P} 5=65: 35$ )

\section{Kadar Protein Terlarut}

\section{Berdasarkan \\ Gambar}

4 ,

peningkatan proporsi tapioka teroksidasi menyebabkan penurunan kadar protein terlarut seasoning meskipun berbeda tidak nyata.

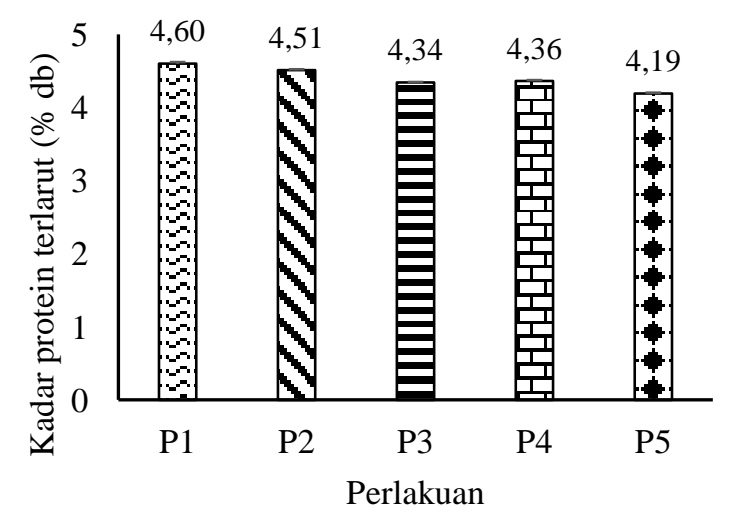

Gambar 4. Kadar protein terlarut seasoning alami pada berbagai proporsi jamur merang terfermentasi dan tapioka teroksidasi $(\mathrm{P} 1=80: 20 ; \quad \mathrm{P} 2=75: 25 ; \quad \mathrm{P} 3=70: 30$; $\mathrm{P} 4=65: 35 ; \mathrm{P} 5=65: 35)$

Kandungan protein terlarut ditentukan oleh banyaknya bubuk jamur merang terfermentasi. Semakin tinggi proporsi tapioka teroksidasi berarti semakin rendah proporsi bubuk jamur merang terfermentasi sehingga menyebabkan penurunan kadar protein terlarut pada seasoning yang dihasilkan.

\section{Produk Maillard}

Berdasarkan

Gambar

5 , peningkatan proporsi tapioka teroksidasi menyebabkan penurunan produk maillard seasoning meskipun berbeda tidak nyata. Hal ini karena kadar protein terlarut seasoning juga berbeda tidak nyata. Produk maillard merupakan reaksi antara gugus amina primer dari asam amino maupun protein dengan gugus karbonil gula pereduksi (Meyer, 1978).

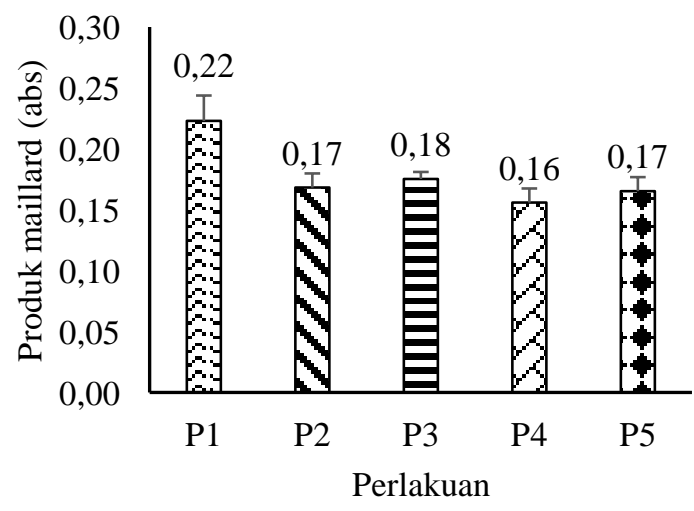

Gambar 5. Produk maillard seasoning alami pada berbagai proporsi jamur merang terfermentasi dan tapioka teroksidasi (P1=80:20; $\quad \mathrm{P} 2=75: 25 ; \quad \mathrm{P} 3=70: 30$; $\mathrm{P} 4=65: 35 ; \mathrm{P} 5=65: 35)$

\section{Daya Larut}

Berdasarkan sidik ragam, proporsi bubuk jamur merang terfermentasi dengan tapioka teroksidasi berpengaruh terhadap daya larut seasoning. Daya larut diukur berdasarkan lamanya seasoning terlarut. Jadi semakin tinggi nilai menunjukkan semakin sulit larut atau daya larut semakin rendah. Peningkatan proporsi tapioka teroksidasi menyebabkan penurunan daya larut (peningkatan waktu larut) seasoning (Gambar 6).

Daya larut ditentukan oleh sifat kelarutan bahan. Bubuk jamur merang terfermentasi lebih bersifat larut dibandingkan dengan tapioka teroksidasi. 


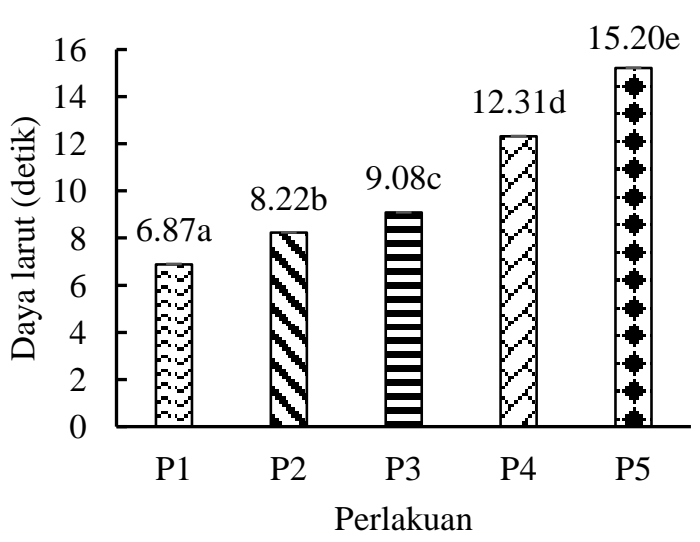

Gambar 6. Daya larut seasoning alami pada berbagai proporsi jamur merang terfermentasi dan tapioka teroksidasi $(\mathrm{P} 1=80: 20 ; \quad \mathrm{P} 2=75: 25 ; \quad \mathrm{P} 3=70: 30$; $\mathrm{P} 4=65: 35 ; \mathrm{P} 5=65: 35)$.

Hal ini karena selama fermentasi jamur merang terjadi hidrolisis komponen-komponen molekul rantai panjang seperti protein, lemak dan karbohidrat. Protein terhidrolisis menjadi asam amino dan peptida sederhana, lemak menjadi asam lemak, karbohidrat seperti pati terhidrolisis menjadi gula-gula sederhana.

\section{Sifat-Sifat Sensoris}

Berdasarkan sidik ragam, proporsi bubuk jamur merang terfermentasi dengan tapioka teroksidasi berpengaruh terhadap kesukaan warna dan rasa, namun tidak berpengaruh terhadap kesukaan aroma dan kesukaan keseluruhan. Nilai kesukaan warna, rasa dan kesukaan keseluruhan tertinggi terdapat pada perlakuan proporsi bubuk jamur merang terfermentasi dengan tapioka teroksidasi 75:25, dengan nilai kesukaan warna, rasa dan keseluruhan berturut-turut 3,28 (agak suka sampai suka); 3,08 (agak suka sampai suka); 3 (agak suka). Nilai kesukaan aroma tertinggi terdapat pada perlakuan proporsi bubuk jamur merang terfermentasi dengan tapioka teroksidasi 60:40, dengan nilai kesukaan 3,12 (agak suka sampai suka) (Gambar 7).

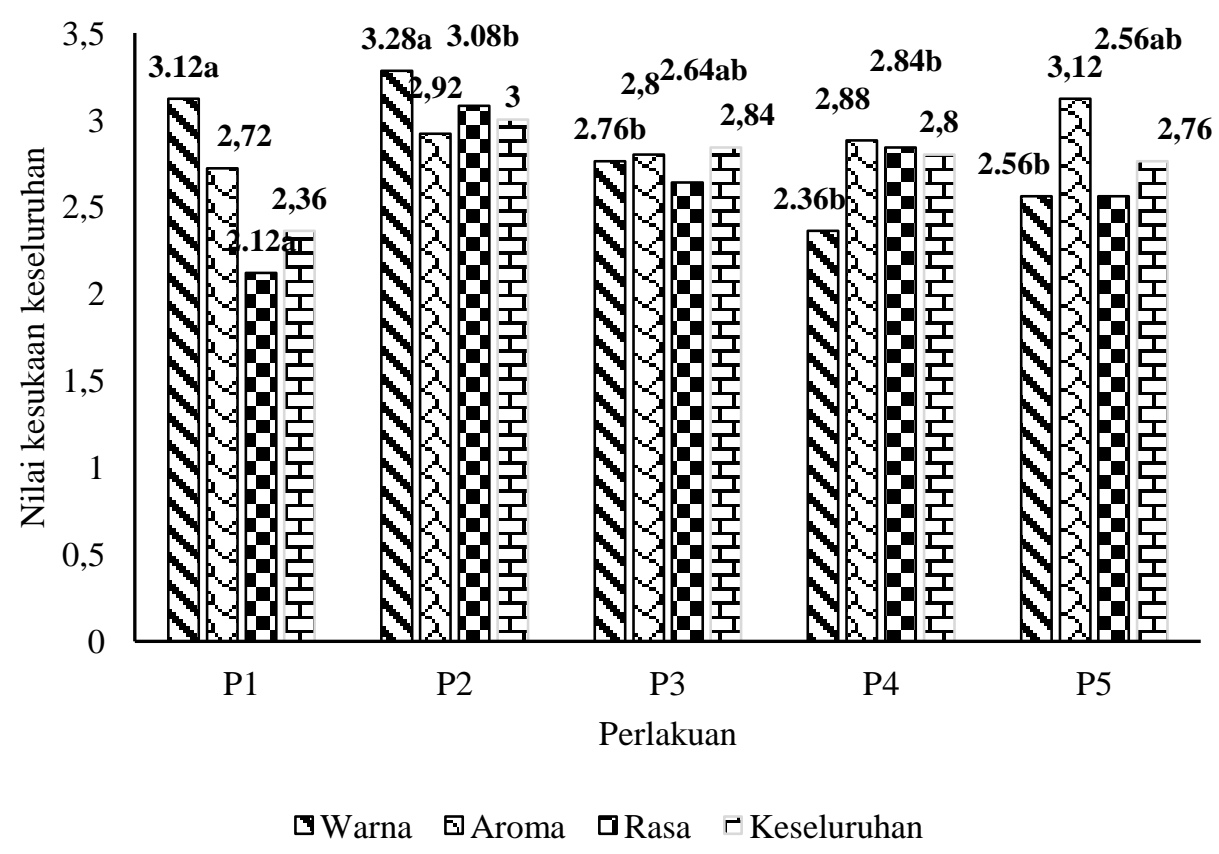

Gambar 7. Nilai kesukaan sensoris seasoning alami pada berbagai proporsi jamur merang terfermentasi dan tapioka teroksidasi $(\mathrm{P} 1=80: 20 ; \mathrm{P} 2=75: 25 ; \mathrm{P} 3=70: 30 ; \mathrm{P} 4=65: 35 ; \mathrm{P} 5=65: 35)$ 
Jadi warna seasoning yang disukai adalah dengan kecerahan sedang. Rasa seasoning yang disukai diduga pada intensitas rasa bubuk jamur yang masih cukup tinggi, sedangkan aroma yang disukai pada intensitas aroma bubuk jamur yang terendah. Nilai kesukaan keseluruhan lebih ditentukan oleh kesukaan warna dan rasa.

\section{Kenampakan Seasoning}

Kenampakan sesasoning ditunjukkan pada Gambar 8. Kenampakan antar perlakuan sulit dibedakan.

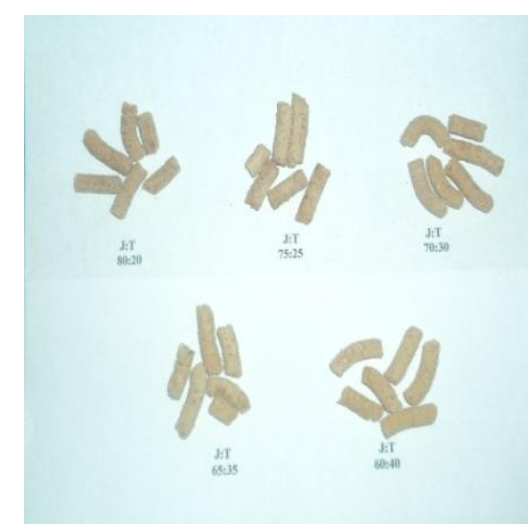

Gambar 8. Kenampakan seasoning alami pada berbagai proporsi jamur merang terfermentasi dan tapioka teroksidasi

\section{Perlakuan terbaik}

Perlakuan terbaik terdapat pada proporsi bubuk jamur merang terfermentasi dengan tapioka teroksidasi 75:25 (P2) seperti ditunjukkan pada Tabel 1.

Tabel 1. Nilai efektivitas seasoning

\begin{tabular}{lc}
\hline \multicolumn{1}{c}{ Perlakuan } & $\begin{array}{c}\text { Nilai } \\
\text { (Proporsi bubuk jamur } \\
\text { merang terfermentasi: } \\
\text { tapioka teroksidasi) }\end{array}$ \\
\hline P1 (80:20) & \\
P2 (75:25) & 0,52 \\
P3 (70:30) & 0,91 \\
P4 (65:35) & 0,61 \\
P5 (60:40) & 0,50 \\
\hline
\end{tabular}

Seasoning yang dihasilkan mempunyai kadar air $14,1 \%$; kadar protein $17,98 \%(\mathrm{db})$ atau 15,48 \% (wb).

Apabila dibandingkan dengan persyaratan SNI untuk penyedap rasa, maka kadar air seasoning yang dihasilkan belum memenuhi persyaratan SNI yaitu maksimal $4 \%$, sedangkan kadar protein memenuhi persyaratan SNI yaitu minimal $7 \%$ (BSN, 2000).

\section{KESIMPULAN}

Berdasarkan hasil penelitian dapat disimpulkan bahwa proporsi yang tepat antara bubuk jamur merang terfermentasi dengan tapioka teroksidasi adalah 75:25. Seasoning yang dihasilkan mempunyai kadar air 14,07 \%, kadar protein 15,48\% (wb) atau $17,98 \%(\mathrm{db})$, kadar protein terlarut 4,37 \% (wb) atau 4,51\%(db), daya larut 8,22 detik, produk maillard 0,168 abs, nilai kesukaan warna 3,16 (agak suka sampai suka), aroma 2,92 (sedikit suka sampai agak suka), rasa 3,08 (agak suka sampai suka), dan kesukaan keseluruhan 3 (agak suka).

\section{DAFTAR PUSTAKA}

Badan Standarisasi Nasional. 2000. SNI-42731996. Syarat Mutu Penyedap Rasa. BSN, Jakarta.

Data Riset Kesehatan Dasar. 2007. Konsumsi MSG di Indonesia.

De Garmo, E. P., Sullivan, W. G., and Canada, J. R. 1984. Engineering Economy. 7 th Ed. Macmilllan Publishing Co. New York.

Depkes R. I. 1988. Daftar Komposisi Bahan Makanan. Bharata Karya, Jakarta.

Drogba, A., Gnopo, J., and Fabrice, A. 2012. Study of physicochemical propertiesof some traditional vegetables in ivory coast; seed of Beilschmiediamannii (Laurceae), seed of Irvingia gabonensis (Irvingiaceae) and (Volvariella volvaceae). Journal of Food Nutrition Science, (3): 14-17. 
Fellow, P. 1988. Food Processing Technology. Principles and Practice. Ellis Horwood Ltd. Chichester. England.

Harmon, R. E., Gupta, S. K., and Johnson. 1971. Oxidation of Starch by Hydrogen Peroxide in the Presence of UV Light. Part I. Die Starke. Vol. 23: 149-158.

Harper, K. and Herpworth, A. 1981. Texture Modifying Agents. Department of Food Studies Queenslands Agricultural College, Lawes, Queenslands.

Kim, J. S., Shahidi, F., and Heu, M. S. 2003. Characteristics of Salt Fermented Sauces from Shrimp Processing by Product. Journal of Agricultural Food Chemistry. (51): 784-792.

Mabesa, I. B. 1986. Sensory Evaluation of Foods Principles and Methods. Laguna. UPLB.

Maslikhah, F. 2015. "Teknologi Pembuatan Bubuk Jamur Merang (Volvariella volvaceae) Terfermentasi”. Skripsi. FTPUniversitas Jember.

Mau, J. L., Chyau, C.C, Li, J. Y and Tseng, Y. H. 1997. Flavor compound in straw mushrooms (Volvariella volvaceae) harvested at difference stage of maturity. Journal of Agricultural Food Chemistry, (45): 4726-4729.

Meyer, L. H. 1978. Food Chemistry. The Avi Publishing Co., Wesport, Connecticut.

Palupi, N. W. 2010. Pengaruh Konsentrasi Hidrogen Peroksida dan Lama Penyinaran UV-C terhadap Tingkat Oksidasi dan Pengembangan Pati Kasava pada Proses Pemanggangan. UGM.

Praptiningsih, Y. and Palupi, N. W. 2014. Characterization of functional properties of oxidized tapioca and sodium alginate. Proceeding of International Seminar ISOSTECH, pp: 99-102.
Palupi, N. W. and Praptiningsih, Y. 2016. Oxidized tapioca starch as an alginate substitute for encapsulation of antioxidant from coffee residue. Agriculture and Agricultural Science Procedia, (9): 304-308.

Parovuory, P., Hamunen, A., Forcel, P., Autio, K., and Pountanen, K. 1995. Oxidation of Potato Starch by Hydrogen Peroxide, Starch/Starke. Vol. 47, pp 19-23.

Sand, J. 2005. Ashort History of MSG: Good Science, Bad Science, and Taste Culture (History of MSG and Its Marketing in Japan, Taiwan, China and the US). Gastronomica, 5: 4.

Sudarmadji, S., Haryono, B. dan Suhardi. 1984. Prosedur Analisis untuk Bahan Makanan dan Pertanian. Liberty, Yogyakarta.

Zayas, J. F. 1997. Functionality of Protein in Foods. Springer. New York.

Zhang, Y., Candrasekar, V., Zhongly, P. And Wei, W. 2013. Recents Developments on Umami Ingridients of Edible Mushrooms. Journal Food Science of Technology, (33): 78-92. 